\title{
Nature, Society and the Spirit: Peter Matthiessen's Ecological Ideas
}

\author{
Jie Han, Liming Zhang \\ Foreign Languages Department, Baoding University, Baoding, China \\ Email: hanjie198262@163.com
}

How to cite this paper: Han, J., \& Zhang, L. M. (2020). Nature, Society and the Spirit: Peter Matthiessen's Ecological Ideas. Journal of Geoscience and Environment Protection, 8, 176-182. https://doi.org/10.4236/gep.2020.811011

Received: November 10, 2020

Accepted: November 22, 2020

Published: November 25, 2020

Copyright $\odot 2020$ by author(s) and Scientific Research Publishing Inc. This work is licensed under the Creative Commons Attribution International License (CC BY 4.0).

http://creativecommons.org/licenses/by/4.0/

(c) (i) Open Access

\begin{abstract}
Peter Matthiessen is widely regarded as a serious, disciplined author who wrote about wild nature, vanishing cultures, and human society. He was a dedicated naturalist from early on, and the concern for nature informed his work from the beginning of his career. This paper analyses Matthiessen's major works from the perspective of ecocriticism, revealing his ecological ideas on natural ecology, social ecology and spiritual ecology respectively. For Matthiessen, the modern environmental crisis is inseparable from social and spiritual problems. He criticizes the anthropocentric and imperial points of view, sparing no effort to pursue justice, harmony and wholeness both in his literary imagination and real life.
\end{abstract}

\section{Keywords}

Nature, Society, Spirit, Peter Matthiessen, Ecology

\section{Introduction}

Peter Matthiessen is widely regarded as a serious, disciplined author who wrote about wild nature, vanishing cultures, and human society. He wrote more than 25 books, including At Play in the Fields of the Lord, Far Tortuga, Shadow Country and In Paradise. As a preeminent American novelist and non-fiction writer, he received critical acclaim and his country's most prestigious literary accolades, including an unprecedented three National Book Awards-the first in 1979 for The Snow Leopard (Contemporary Thought), a second (General Non-fiction) for the same work in 1980, and a third award in 2008 for Shadow Country (Fiction). These honors and others confirm his position in the vanguard of late 20th century American literature.

Matthiessen was a dedicated naturalist from early on, and the concern for nature informed his work from the beginning of his career. "In his first nonfiction 
book, Matthiessen staked out the territory he would revisit the rest of his life-the destruction of nature and natural peoples at the hands of mankind" (Vitale, 2014). Both his fiction and non-fiction works reveal the destructive power of technology and industrialization along with the author's concern for the natural world. Matthiessen felt bound to nature physically and spiritually, and he believed that nature is not different or separate from humanity in that both necessarily come from and belong to the same eco-system. William Dowie regards him as a direct descendant of 19th century American Transcendentalists with his belief in the "restorative, pedagogical, and spiritual powers of nature" (Dowie, 1991). Matthiessen is also widely acknowledged as a philosophical guru for those concerned with the environment (Wroe, 2012).

"The earth is in distress and is calling to us, sending us signs of the extremity of its imbalance..." Facing the serious environmental crisis, writers, scholars, environmentalists are responding swiftly. Peter Matthiessen, as a nature and travel writer and a novelist, focuses his attention on the wild places, the wild animals, and "those who cannot speak for themselves". "Sons and daughters of Thoreau abound in contemporary American writing, if we can believe the reviewers", wrote Edward Abbey, one of the literary progeny, himself. One of those he had in mind was Peter Matthiessen, whom he dubbed "the Thoreau of Africa, South America, the Himalaya, and the wide, wild sea”. Matthiessen's major works present his meditation on the conflicts between science and spirit and a modern solution. He hopes to find a balance between them.

This paper, by close reading, analyses Matthiessen's major works from the perspective of ecocriticism, revealing his ecological ideas on natural ecology, social ecology and spiritual ecology respectively. My study assumes that an ecocritical approach is suitable for the analysis of Matthiessen's work and that previous research remains incomplete. My research is dedicated to the further study of Matthiessen's work by focusing on the ecocritical themes and ideas reflected in his major publications, including At Play in the Fields of the Lord, Shadow Country, the Snow Leopard, The Cloud Forest and In Paradise. I have chosen these novels and short stories because each is representative of a particular period in Matthiessen's literary career. Building on existing research, my study will focus on the unique quality of Matthiessen's ecological understanding and the evolution of his ecological ideas as revealed in his major works. As Tredinnick argued in The Land's Wild Music, "Peter Matthiessen's work has also changed, I think, the tide and current, the tone, of nature writing" (Tredinnick, 2005). My hope is that such an inquiry could extend the critical understanding of his work through a focused, deep exploration from an ecocritical perspective.

\section{Literature Review}

Following the publication of his fourth novel, At Play in the Fields of the Lord (1965), Matthiessen began to accrue critical attention. Available sources from his early career are limited to interviews and reviews of his major works, published 
in literary journals, national newspapers, and academic reviews. Examples include an interview by Kay Bonetti in the Missouri Review and a featured article in Time Magazine. Most of the reviews from newspapers and magazines emphasize the themes in individual works and Matthiessen's experimental prose techniques. Compared with other writers of his caliber, scholarly criticism of Matthiessen is lacking.

Form has been an important aspect of the study of Matthiessen's Far Tortuga. Grove studied the pastoralism and anti-pastoralism in Far Tortuga and saw the impressionistic form in it. Patteson examined the Holistic Vision and Fictional Form of this novel and mentioned that "man is part of, and dependent upon, an interconnected system greater than himself" (Patteson, 1983). Bert associated the novel with American sea fiction since Moby-Dick (Bert, 1984). Raglon also investigated the ecological form in Far Tortuga, maintaining that a tension is found in Matthiessen's work that accounts for his frequent oscillation between fact and fiction (Raglon, 1994). Marie-Christine and Noailles-Pizzolato focus on the interaction between the intricate artistic forms and the writer's presentation of nature and ecology in Far Tortuga (Noailles-Pizzolato, 2016).

In his 1991 work, William Dowie introduced Matthiessen and his major works in general. Dowie's monograph, probably, is the first major scholarly review of Matthiessen's work available. There is also a comprehensive bibliography by Roberson, Peter Matthiessen: An Annotated Bibliography, which centers on book reviews, dissertations, and annotations (Roberson, 2001). This comprehensive annotated bibliography may help the reader better their understanding of Matthiessen and his major works. As evidenced by these disparate investigations, early scholarship on Matthiessen was unsystematic, limited in scope, and lacking a diversity of critical approaches.

As Michael Dirda mentioned: "No one writes more lyrically [than Matthiessen] about animals or describes more movingly the spiritual experience of mountaintops, savannas, and the sea" (Dirda, 2008). Therefore, an ecocritical approach is a fitting academic lens for the appraisal and interpretation of Matthiessen's body of work. A number of the aforementioned articles are related to ecocriticism, and contemporary researchers have conducted related explorations. Intaek Oh's short monograph Peter Matthiessen and Ecological Imagination seeks to reveal issues Matthiessen has been exploring both in his fiction and nonfiction. Oh posits that "for Matthiessen, economic, political, social, racial, psychological, epistemological, and ecological issues are all inseparably interconnected" (Intaek, 2010). While Intaek Oh's book engages in an ecocritical reading of the Watson Trilogy, Shin Yamashiro's dissertation focuses on the environmental justice in Matthiessen's works.

\section{Theoretical Framework}

This paper takes ecocriticism as its theoretical framework, setting Matthiessen in the context of the global ecological crisis. It tries to make a systematic and comprehensive analysis of Matthiessen's ecological ideas from the perspective of 
natural ecology, social ecology and spiritual ecology, in the hope that this would contribute to the study of Matthiessen and his works.

Ecocriticism is a broad way for literary scholars and critics to study ecological issues from an interdisciplinary point of view. As Glotfelty and Fromm wrote in The Ecocriticism Reader: Landmarks in Literary Ecology:

Ecocriticism is the study of the relationship between literature and the physical environment. Just as feminist criticism examines language and literature from a gender-conscious perspective, and Marxist criticism brings an awareness of modes of production and economic class to its reading of texts, ecocriticism takes an earth-centered approach to literary studies (Glotfelty \& Fromm, 1996).

While postcolonialism is often associated with the anthropocentric view and concerned with social justice, postcolonial ecocriticism seeks to study the intersection between postcolonial criticism and ecocriticism, which share similar concerns in many ways (Nichols, 2011). Postcolonial ecocriticism ushered in fresh perspectives with which to examine ecological issues in former colonies, and Peter Matthiessen's work offers an array of narrative ideas and perspectives that can be seen as parallel and complimentary in their explication of the ecological impact and consequences of colonial expansion. Importantly, Matthiessen's work also explores the related social, psychological, and cultural costs of such expansion using an ecological framework.

Postcolonial ecocriticism is a branch of ecocriticism which centers on the interrelationship between postcolonialism and ecocriticism.

Any field purporting to theorise the global conditions of colonialism and imperialism (let us call it postcolonial studies) cannot but consider the complex interplay of environmental categories such as water, land, energy, habitat, migration with political or cultural categories such as state, society, conflict, literature, theatre, visual arts. Equally, any field purporting to attach interpretative importance to environment (let us call it eco/environmental studies) must be able to trace the social, historical and material co-ordinates of categories such as forests, rivers, bio-regions and species. Postcolonial ecologies are closely related to social and environmental justice, ecological imperialism, and racism.

\section{Natural Ecology}

Natural ecology refers to the natural world. It is concerned with the relationship between man and nature (environment). Matthiessen criticizes the man/nature dichotomy and advocates a harmonious and interactive relationship between man and nature.

Matthiessen describes his impression on the pollution of Nepal in this way: "With its rapidly increasing population, primitive agriculture, and steep terrain, Nepal has the most serious erosion problem of any country in the world, and the problem worsens as more forests disappear in the scouring of the land for food and fuel" (Matthiessen, 2009), and he contends that the clear and glisten galaxy is hidden in the western world due to the severe air pollution caused by human 
activities. The shift from anthropocentric dualism to an earth-centered value system is the core of Matthiessen's ethic.

In Cloud Forest, Matthiessen gives ironic depiction of the shooting of birds, he explains that "Interference with the balance of nature, as well as the senseless killing so common on this continent, were primary factors in the decimation of wildlife in North America and are making their mark here, a half-century later." Meanwhile, the Indians pursue the wild animals, which are disappearing, everywhere. "Man has literally scratched the surface of this enormous world" (Matthiessen, 2009).

\section{Social Ecology}

Social ecology is closely related to the work of Murray Bookchin, and he argues that violence against the natural world has its origin in human social and economic institutions based on oppressive systems of hierarchy and elitism. He also maintains that a wild, unaltered ecosystem is "of unity in diversity, spontaneity and complementary relationship, free of all hierarchy and domination".

Another important figure associated with the term is Lu Shuyuan, an eminent eco-critic in China, who specializes in the studies of ecological literature and the arts. He proposes that "social ecology takes politics and economy of human society as its object of study". The first definition centers on "hierarchy and domination", while the second one lays emphasis on "politics and economy". To some extent, these two definitions are complementary to each other. Thus, this thesis will take these two definitions into consideration.

For Matthiessen, environmental problems are reflections of social and spiritual problems in human society. He probes social and political issues like racism, capitalism, technology and colonialism in works like At Play in the Fields of the Lord, Shadow Country and In Paradise. The story of Edgar Wason is not only a life experience of the character, but also a tragic account of the life of American people. By depicting the natural disaster in the frontier, the novel reveals the possible underlying causes of the problem, such as war, racial discrimination and exploitation.

\section{Spiritual Ecology}

Spiritual ecology is a relatively new term that refers to the intersection between religion and spirituality and environment. It "explores the interface of religions and spiritualities on the one hand, and environments, ecologies, and environmentalisms on the other". In China, Lu Shuyuan defines "spiritual ecology" as the relationship between the spiritual subjects (mainly human being) and the environment. Social ecology is, to some extent, related to Transcendentalism.

It is hard to define Transcendentalism due to its complexity. Emerson once stated "What is popularly called Transcendentalism among us, is Idealism; Idealism as it appears in 1842". He also claimed that "Transcendentalism is the Saturnalia or excess of Faith". Transcendentalism is a combination of compli- 
cated philosophical and religious ideas. The transcendentalist laid emphasis on spirit, or the Oversoul, as the most important thing in the universe. They also paid attention to the importance of the individual, who was regarded as the most important aspect in society. More importantly, they regarded nature as symbolic of the Spirit or god. Nature was alive, and "it was the garment of the Oversoul". Thus, it could exert an important influence on the human mind. The transcendentalist advocated that "go back to nature, sink yourself back into its influence, and you'll become spiritually whole again". They were, by and large, pioneer of the modern environmental movement, and protector of nature. Their ideas may shed light on our understanding of contemporary social and environmental crisis.

The writings of Emerson, Thoreau and Muir, as American classics, have exerted positive and enduring influence on the Deep Ecology Movement and environmental philosophy in 21 st century.

Matthiessen, as a matter of fact, was deeply influenced by Zen (a school of Mahayana Buddhism that aims at enlightenment by direct intuition through meditation). Zen "provided Matthiessen with a religious context for his habitual posture toward the world" (Dowie, 1991). For him, the environmental crisis is essentially associated with the spiritual crisis that exists within the mind of modern people. It is of vital importance that we change our anthropocentric beliefs and reconnect ourselves with the earth. As Dowie mentioned in his monograph, Matthiessen's (1978) Snow Leophard and Nigh-Headed Dragon River (1985) give detailed accounts of his religious journey and his spiritual commitment.

In Snow Leopard, Matthiessen explains that "we take for granted that instinct for survival, fear of death, must separate us from the happiness of pure and uninterpreted experience, in which body, mind, and nature are the same." Human beings are part of nature and "in unison with" nature. However, "Man has closed himself up, till he sees all things through the narrow chinks of his cavern". Literally, the harmony between physical and spiritual life can and will be a solution to the contemporary environmental crisis.

\section{Conclusion}

Peter Matthiessen's ecological ideas concerning natural, social and spiritual ecology are influenced by Transcendentalism and Zen Buddhism. In his major works, these three aspects, namely the relationship between man and nature, man and society, man and himself/herself as well as man and the divine are interconnected. For Matthiessen, the modern environmental crisis is inseparable from social and spiritual problems. He criticizes the anthropocentric and imperial points of view, sparing no effort to pursue justice, harmony and wholeness both in his literary imagination and real life.

\section{Acknowledgements}

This paper is under the project of The Cultivation of Culture Awareness in Eng- 
lish Literature Teaching and the project of The Application of Project-based Learning in Teaching Oral English. I am deeply indebted to all the team members, who offered invaluable advice and comments.

\section{Conflicts of Interest}

The authors declare no conflicts of interest regarding the publication of this paper.

\section{References}

Bert, B. (1984). Far Tortuga and American Sea Fiction since Moby-Dick. American Literature, 56, 227-248. https://doi.org/10.2307/2925755

Dirda, M. (2008). An Epic of the Everglades, the New York Review of Books. https://www.nybooks.com/articles/2008/05/15/an-epic-of-the-everglades

Dowie, W. (1991). Peter Matthiessen. Boston, MA: Twayne Publishers.

Glotfelty, C., \& Fromm, H. (1996). The Ecocriticism Reader: Landmarks in Literary Ecology. Athens: The University of Georgia Press.

Intaek, O. (2010). Peter Matthiessen and Ecological Imagination. New York: Peter Lang.

Matthiessen, P. (1978). The Snow Leopard. New York: The Viking Press.

Matthiessen, P. (2009). The Cloud Forest. London: Harvill Secker.

Nichols, M. (2011). Postcolonial Ecocriticism: Literature, Animals, Environment by Graham Huggan and Hellen Tiffin. Critical Quarterly, 53, 100-105. https://doi.org/10.1111/j.1467-8705.2011.01981.x

Noailles-Pizzolato, M.-C. (2016). Nature Pictures in Peter Matthiessen's Far Tortuga. Interdisciplinary Studies in Literature and Environment, 23, 821-834. https://doi.org/10.1093/isle/isw076

Patteson, F. R. (1983). Holistic Vision and Fictional Form in Peter Matthiessen's Far Tortuga. Rocky Mountain Review of Language and Literature, 37, 70-81. https://doi.org/10.2307/1347269

Raglon, R. (1994). Fact and Fiction: The Development of Ecological Form in Peter Matthiessen's Far Tortuga. Critique: Studies in Contemporary Fiction, 4, 245-259. https://doi.org/10.1080/00111619.1994.9934707

Roberson, W. (2001). Peter Matthiessen: An Annotated Bibliography. Jefferson, MO: McFarland Publishing.

Tredinnick, M. (2005). The Land's Wild Music. San Antonio, TX: Trinity University Press.

Vitale, T. (2014). Peter Matthiessen, Co-Founder of the Paris Review, Dies at 86. NPR. https://www.kpbs.org/news/2014/apr/06/peter-matthiessen-co-founder-of-the-paris-re view

Wroe, N. (2012). Profile: Call of the Wild. The Guardian, 12. 